\title{
CÓRREGO GRANDE REVISITADA
}

Renate B. Viertler 
Iniciei minhas pesquisas de campo entre os bororo em 1970. Primeiro em Sangradouro, quando conheci o índio José Maria Mano Kurireu e também o padre Cesar Albisetti. Meus primeiros planos limitavam-se à iniciação no aprendizado da língua deste grupo indígena. Recordo-me bem do peso do ambiente, da solidão e do sonho em querer mergulhar no mundo dos bororo. Voltei a eles num outro estágio de campo, em meados do mesmo ano, retorno profundamente marcado pelo trabalho desenvolvido com o velho bororo, Hugo Airugodo, na aldeia de Córrego Grande.

Minhas conversas com Hugo desenvolviam-se no Posto. Recebia-o todos os dias para nossos papos, acompanhados sempre de ca.fés e bolachas. Por vezes, meu amigo adormecia na rede, visivelmente desmotivado e um tanto cansado com as perguntas descabidas, gravadas em fitas, que retratam a situação grotesca de um início de aprendizado. Mestre de incansável paciência e enorme zelo, Hugo iniciou-me nos significados dos "silêncios" e na dolorosa sensação de que certas coisas "são" e "não são" ao mesmo tempo, abalando profundamente os meus referenciais imaginados à base da leitura de obras etnológicas.

O mais desesperador para mim era quando, em suas explicações, Hugo recorria a fragmentos de tradições orais em sua língua nativa, momentos estes em que, desorientada pela interrupção, eu me desligava abruptamente do nosso fluxo de comunicação, pois, não falando Bororo, não conseguia captar o essencial de suas respostas.

Lembro-me da Córrego Grande desta época: o chefe de Posto havia se retirado, substituído que fora por um braçal da Funai, e os bororo eram liderados por um grande chefe, o bororo Cuabori, "o que sabia muito" seguido de uma plêiade de outros chefes clânicos tais como Hugo e Kadagare, que nos receberam muito bem.

Instalei-me com os demais integrantes da equipe de pesquisadores, na casa do Posto, e poucas vezes ia à aldeia, já que Hugo preferia falar a sós comigo, longe dos olhares atentos e eventuais críticas de outros bororo. Como retribuição, ofereci-lhe o correspondente à jornada de trabalho vigente na região e ofertava-Ihe, vez ou outra, alguns presentes. Marcante foi, para mim, o aprendizado de um tipo de Português, adotado por ele, que passei a usar entre os bororo nas pesquisas subseqüentes: frases curtas, iniciadas em tonalidade mais 
aguda e finalizadas em tonalidade mais baixa de voz, pequenas pausas entre as frases (o que me causava bastante estranheza na época).

O foco de nossas conversas era representado pelo modelo ideal das aldeias bororo e pelas práticas de nominação, assunto que Hugo tratava com especial carinho. Foi dessa perspectiva que aprendi a ver o mundo dos bororo, resultado do trabalho com este velho pensador, membro do restrito grupo "dos que sabem", realçando reflexões que jamais voltaria a encontrar. Senti claramente que, após a morte do meu mestre, eu deixara de ter o interlocutor certo para este tipo de conversa.

Eu também havia passado por fortes transformações depois de voltar ao campo, em 1977 após um longo estágio no Exterior para trabalhar, à distância, sobre os dados obtidos em Córrego Grande. A morte de parentes e a ruptura de um relacionamento conjugal modificaram-me profundamente.

Retomei a pesquisa em Tadarimana, aldeia onde reencontrei, pela primeira vez, após a morte de Hugo, Canajó, seu genro, e Natividade, sua filha. A retomada de nosso relacionamento obedeceu a um certo ritual - em nome do finado, Natividade saudou-me com lágrimas e pranto ritualizado, quando me reconheceu nas ruas de Rondonópolis. Convidaram-me para morar em sua choupana, na aldeia. Acatei prontamente o convite, pois, na verdade, eu iria ficar no lugar associado a um morto querido. Meus sentimentos contribuíram para esta opção, reforçada pela possivel integração afetiva de todos os meus mortos: pai, mãe, tias, marido, Hugo. Emergia em mim o interesse pelos mortos e suas celebrações, assuntos tão caros a Canajó e aos diversos bororo de Tadarimana.

Nesta fase, desenvolvi um relacionamento apenas cordial com o chefe de Posto local e sua mulher. Tadarimana parecia-me um campo de forças antagônicas: se eu fosse me relacionar melhor com o chefe de Posto, desagradaria aos bororo, e, se me relacionasse melhor com estes últimos, irritaria o referido casal. Embora eu tivesse optado por uma política de boa vizinhança em relação ao casal de brancos (eu e uma aluna íamos "tomar leite" em sua casa), achava que o peso dos meus esforços e atenções deveria pender para o lado dos bororo. Durante o funeral de 1978, emergiu claramente a tensão latente entre a antropóloga e o chefe de Posto. Naquela oportunidade, este afirmou, 
por intermédio da facção dos bororo a ele ligada, que estaríamos causando distúrbios com as fotos e as gravações feitas em nosso levantamento etnográfico.

Nesta época, estava em marcha a deterioração das condições gerais de vida na aldeia, e dizia-se que Tadarimana não era uma comunidade politicamente bem-estruturada, já que lá não havia chefes de muita influência. $O$ faccionalismo era forte, o que impedia um alinhamento mais coerente das forças políticas internas, diferentemente de Córrego Grande, por exemplo, mais coesa, sob a liderança segura do bororo Kadagare.

Cheguei a entender também que a "política funerária" só pode ser desempenhada por aldeias "fortes" tais como Córrego Grande e Meruri. A primeira, Córrego Grande, agora minha vizinha, parecia-me uma ameaça aos líderes de Tadarimana, aldeia onde Canajó conseguiu convencer os demais bororo a realizarem o meu "batizado", quando recebi o nome de "Barameri Ekureudo" (que significa "O morro de Barame" um herói intelectual, amarelo). Tadarimana era, pois, a "minha aldeia", o "meu lugar" no mundo bororo, onde havia a "minha casa", hospitalidade, comida e afeto à minha espera.

Não imaginava que este idílio tivesse tão amarga contrapartida. De início, tentei ocultar de mim mesma os problemas, atribuindo-os a idiossincrasias dos meus hospedeiros. $O$ batizado de um civilizado possui o significado de uma estratégia social sui generis: exercer pressão moral sobre o nominado para que este preste favores e traga presentes para o nominador. Se evocarmos a história dos contatos interétnicos, poderemos observar que, nas fases iniciais do contato, os bororo costumavam usar os nomes dos brancos que os haviam submetido. Isto mostra que as práticas de nominação, quando feitas entre bororo e civilizados, refletem atitudes éticas que nada têm em comum com os valores de nossa visão cristã: amizade, generosidade, proteção. Pelo contrário, assumem o sentido de imposição. No caso do nominador ser bororo, a imposição se faz na direção dos "vencidos" (os bororo derrotados e subordinados ao branco) sobre os "vencedores" (os brancos que dominam os bororo), expressão de um ver- 
dadeiro "ritual de rebelião" que chega ao seu máximo por ocasião dos funerais, quando os bororo literalmente comandam tudo o que acontece nas reservas.

Para mim, a experiência de "receber nome" associou-se a um forte sentimento de ser alvo de "extorsões" por parte dos meus nominadores, preocupados que estavam em obter bens manufaturados, seduzidos pelo "fascínio" exercido pelos produtos da civilização, como tem sido freqüentemente registrado nos relatos dos antropólogos. A vivência real deste processo foi extremamente penosa, fazendo com que eu me sentisse impelida a sair da choupana dos meus nominadores, então sob um clima muito tenso, e me transferisse para a escola de Tadarimana. Além de evitar o impacto representado pelos pedidos, eu visava também neutralizar o ressentimento dos bororo das outras choupanas que, evidentemente, não conseguiam ter acesso aos benefícios trazidos pelas antropólogas.

A relação entre mim, meu nominador e os outros bororo com os quais conversei não podia mais ser "construída" de modo calmo, "sem pressa", como havia sucedido com Hugo. A vida na aldeia tornara-se agitada e minhas conversas sofriam a interferência clara dos diálogos què haviam sido mantidos por antropólogos que me precederam. Isto porque a maioria dos bororo sempre remete o pesquisador "àqueles que sabem", um número reduzido de adultos e velhos do sexo masculino, grupo que acaba monopolizando as atenções dos diversos antropólogos que vêm a campo. Assim, um deles disse-me certa vez: "Eu já sei o que você quer. Senta aí e anote no seu caderno!" sem que eu tivesse formulado qualquer pergunta. Quando as indagações versavam sobre assuntos não "catalogados", as respostas eram demoradas, reticentes ou simplesmente ausentes.

Foi em Tadarimana que se configurou, para mim, uma prática de barganha política que viria a ter um peso cada vez maior: a cobrança, por parte das comunidades, de um "preço de entrada" na reserva visitada pelos antropólogos. Em 1977 os bororo de Tadarimana haviam se contentado com roupas usadas em quantidade razoável que havíamos reunido, além de anzóis, linhas, agulhas, mate, pão. Diziam terem ficado "muito alegres" razão pela qual chegaram a cantar após a nossa entrada e, posteriormente, a realizar o mencionado batizado.

Já em 1982, as lideranças locais se manifestaram contrárias ao 
ingresso de nossa equipe, já que não havíamos pago o preço estipulado: "um caminhão" Exigimos junto à Funai o direito de negociar diretamente com as lideranças, que, por sua vez, se referiram a um "papel", supostamente de minha autoria, que conferia referências ofensivas aos bororo. Consultados por representantes da Funai quanto ao nosso ingresso na reserva, e ressentidos, os bororo acabaram acatando os "conselhos" dos representantes do órgão tutelar, no sentido de exigir presentes muito caros para compensar as acusações de que bebiam muito e trabalhavam pouco. Em 1978, se esboçara esta tendência de compensar ofensas por meio de "presentes" caros, tal como se pode avaliar pelo seguinte: tendo passado por Brasília, encontrei um antropólogo da Funai que me garantiu ser possível ajudar a um bororo de Tadarimana a fazer a sua mudança por meio de um caminhão que, saindo do Meruri, onde estavam os pertences deste índio, chegaria até Rondonópolis, perto de Tadarimana, a aldeia onde ele morava.

Enviei carta a este bororo, sugerindo-Ihe que fosse ao Meruri para transferir os seus patos, galinhas, instrumentos de ferro, máquina de costura etc. contando com a ajuda da Funai. $O$ bororo chegou ao Meruri, por conta própria, apresentou-se ao referido antropólogo, mas este último garantiu-lhe que não falara comigo. Furioso, nosso índio foi obrigado a vender por uns trocados a sua máquina de costura e a voltar para casa. Segundo minha interpretação, o dano havia sido causado pelo antropólogo da Funai, mas para o bororo, por minha "palavra" (carta), versão esta que me foi veiculada por carta do chefe de Posto. Achei que devia fazer "mori" - compensar os danos comprando-Ihe outra máquina de costura pelo que ele ficou "muito alegre" e me convidou a assistir a um funeral, em 1978.

A Funai se valeu da idéia de "compensação por danos", pois dispunha de um "bode expiatório": os antropólogos que, de certo modo, não conseguiam desenvolver relações construtivas com os funcionários locais. É claro que os "estragos" ou "ofensas" eram causados pela deterioração das condições das comunidades indígenas no tocante à terra, às condições gerais de sobrevivência e à intensificação do consumo de bens industrializados.

Vivenciei esta fase marcada por um antagonismo entre antro- 
pólogos e representantes da Funai, o que influenciou em muito as minhas atitudes, comportamentos e também a produção acadêmica.

Com relação às ofensas aos bororo a nós atribuídas ressalto: a Delegacia Regional da época falava abertamente em "alcoolismo" ou "indolência no trabalho da roça" sem que houvesse quaisquer reações por parte dos bororo. 0 mesmo acontecia com os funcionários locais - chefe de Posto, enfermeiras, professoras, com os quais havíamos trocado impress ̃̃es sobre os "problemas sociais" das aldeias. Contudo, dado o clima ambíguo de relacionamento entre aqueles funcionários e antropólogos, houve a possibilidade de usar tais constatações, sociológica e antropologicamente irrefutáveis, contra os próprios antropólogos. O pesquisador que ousasse enunciar os estereótipos do "bororo beberrão" e "indolente" de forma aberta poderia contar com o "fechamento" da reserva.

Mentiria se afirmasse que viver entre pessoas muito inclinadas à bebida não é difícil e nem desgastante. Contudo, lá onde vivo, no campo, não me é permitido dizê-lo abertamente: trata-se de uma questão de sensibilidade e de etiqueta social. Fazê-lo seria expor-me às críticas não só dos próprios bororo, mas também dos funcionários locais que, radicados entre os índios, devem-Ihes apoio moral sob todas as circunstâncias. Aprendi de forma penosa que os bororo estabelecem uma grande diferenciação de comportamentos e expectativas conforme os brancos sejam radicados (chefes de posto, enfermeiras, professores, missionários) ou não-radicados (equipes volantes de médicos, técnicos, antropólogos, avaliadores de projetos etc.) nas reservas.

Os brancos "não-radicados" (ou "flutuantes") são tratados de forma que a médio ou longo prazo a sua permanência nas aldeias se tornaria inviável. Visto tratar-se de civilizados que "não voltam" (por mais que se volte, os bororo afirmam que a gente "não volta", quando se despedem), justifica-se, para os bororo, usá-los e "extorqui-los" da forma mais rápida e sistemática possível. Segundo o chefe de Posto de Córrego Grande, em 1986, os bororo gostam que os antropólogos morem na aldeia com o intuito de facilitar tais estratégias, e não porque "gostem" deles ou sintam alguma "amizade" 
Esta relação de espoliação torna-se inviável nos contatos entre bororo e brancos radicados na reserva, que sucumbiriam, assim, pela exaustão psíquica e pela miséria, se colocassem em prática padrões de convivência pouco duradoura que presidem as relações entre bororo e antropólogos.

Em meu estágio na Córrego Grande de 1986 foi-me dado desenvolver um padrão de relacionamento "misto": entrei na reserva na condição de "antropóloga", pelo que tive que realizar duras barganhas, como se verá mais adiante; obrigada a morar no Posto para ficar mais próxima de meu principal informante, o chefe Kadagare, acabei por me integrar nas atividades desenvolvidas pelo pessoal da Funai, coisa que em muitos momentos me protegeu contra os avanços predadores de determinados bororo mais radicais.

Esta convivência diária com o pessoal local abriu-me uma nova dimensão para a análise: a Funai, longe de ser um referencial monolítico, deve ser concebida em termos de uma divisão clara entre "pessoal da Delegacia Regional", radicado em Cuiabá, subordinado à Brasília, e "pessoal local" radicado na reserva.

A defasagem de valores e procedimentos entre os dois níveis de integração da Funai é importante para a compreensão das dificuldades financeiras e políticas que se abatem sobre o chefe do Posto. Do ponto de vista econômico, emergem problemas relativos à liberação de verbas causados pela morosidade da burocracia administrativa de Cuiabá e de Brasília; do ponto de vista político, não existem controles sobre o tempo de permanência e as saídas da reserva de enfermeiras, professoras e atendentes de enfermagem, administrativamente subordinadas a responsáveis radicados em Cuiabá. A coordenação destes dois domínios - escola e enfermaria - acrescida dos problemas políticos causados pela invasão das terras da reserva, além de rixas entre as diversas facções da comunidade bororo, das queixas de todos eles com relação ao atendimento médico e escolar e dos malabarismos necessários para prover o transporte para doentes, parturientes, vendedores de artesanato, compradores de bens em Rondonópolis e Cuiabá, parentes de doentes e falecidos, lavradores de fazendas vizinhas etc. elevam o chefe de Posto à condição de "demiurgo" neste verdadeiro caos social. 
Daí cada chefe de Posto desenvolver uma "filosofia" e adotar "lemas" para orientar a sua atuação, altamente individualizada, frente a tal multiplicidade de funções superpostas. Para os bororo, ele é um "pai" com o qual é possível brigar, até mesmo em termos físicos, sem que se rompa este laço de tamanha importância social e afetiva. Evidentemente, os diversos chefes de Posto podem ser mais ou menos envolvidos afetivamente por suas funções sociais nas reservas, assim como pode haver enfermeiras mais ou menos "formais" ou "higienizantes" no desempenho de suas atividades junto às populações indigenas. Tais variações de conduta suscitam respostas diversas por parte dos bororo que, extremamente rigorosos nas suas avaliações no tocante ao atendimento médico, não vacilam em expulsá-las da reserva. Presenciei uma situação deste tipo quando de minha estada em Córrego Grande, ocasião em que constatei que os "descuidos" a elas imputados encobrem, na verdade, infrações contra a hierarquia de autoridade dentro da comunidade.

Portanto, permanecem como "radicados" nas reservas os civilizados da Funai que conseguirem se adaptar à hierarquia do poder comunitário local.

Durante o meu estágio em Córrego Grande empenhei-me, ao máximo, em seguir rigorosamente os ditames desta hierarquia de prestígio em cujo topo, apesar de todas as divergências, continuava pairando o chefe bororo Kadagare, que morava perto do Posto, longe da aldeia. Em caso de dúvidas quanto ao meu procedimento, informava-me com outros bororo sobre o modo correto de agir, para não ferir suscetibilidades. E, por todas as vias, a última palavra era sempre a de Kadagare, expressão não apenas da supremacia de um clã, mas também da supremacia dos "velhos" da aldeia.

$\mathrm{Na}$ parlamentação que desenvolvi com os chefes para poder entrar na reserva, os "jovens" argumentaram enfaticamente que eu não tinha o direito de ficar porque meu dinheiro era escasso (um total de $\mathrm{Cz} \$ 4500,00$, dos quais 1500,00 , já haviam sido dispendidos em mate e açúcar para todos por ocasião de minha chegada, restando-me apenas $\mathbf{3 0 0 0}$ para cobrir alguma prioridade da comunidade).

Fato é o que os "jovens", falando bem o português, haviam estado em contato, poucos dias antes de minha chegada à reserva, com a equipe de avaliadores da Pólo Noroeste, quando se falou de somas vultosas de dinheiro. 
Falei aos bororo que eu nada tinha a ver com os projetos da Pólo Noroeste, que eu não era "americano" I o "norte-americano" que pouco tempo antes estivera na reserva e distribuíra presentes, o que não impediu que fosse "saído" precipitadamente da reserva), muito menos "padre", "fazendeiro" ou "deputado", todos associados à posse de muitos recursos financeiros. "O meu dinheiro é pequeno" dizia-lhes, "e meu trabalho resume-se em coletar as tradições que os velhos carregam consigo quando morrem e que os jovens não querem ou não podem mais aprender" "Boe jokodo! (E verdade!)" resmungaram os velhos sentados na minha frente. Instaurou-se um longo silêncio. Nenhuma resposta. Falei: "Posso ir embora com o chefe amanhã! Não tem nenhum problema." Os velhos: "Você fica porque os seus chefes te mandaram com mate e açúcar e a gente não pode mandar você embora assim, sem nada. Mas você tem que voltar fazendo mais força. Uns 10 mil assim, 3 mil é muito pouco!"

Mais tarde, ouvi um bororo da "ala jovem" dizer que eu havia "passado conversa nos velhos" mas nada mais sucedeu até o fim de minha estada.

O dinheiro e a presença de avaliadores da Pólo Noroeste criaram problemas para uma enfermeira no Piebaga, expulsa da área pelos bororo, com a promessa da Pólo de que uma outra lhes seria providenciada, o que, aliás, acabou não acontecendo; problemas para o chefe de Posto de Córrego Grande, excluído do trabalho de avaliação em sua reserva, onde atua há mais de quatro anos; problemas para mim, desprovida de vultosas verbas em área tão carente de recursos, ameaçando seriamente pesquisas não-engajadas na política de desenvolvimento preconizadas pelas forças financeiras. $O$ fato que mais me chocou é que tal política é levada adiante por antropólogos que deixaram de se basear num princípio fundamental subjacente a toda a Antropologia: o da necessidade de se aceitar, antes de mais nada, o imperativo de fazer um levantamento sério, o mais sistemático possível, na situação peculiar de contato com o campo das forças sociais a serem avaliadas, com o máximo de respeito por todos os envolvidos na situação. No caso, tais forças são representadas não apenas pelos bororo, ou, melhor dizendo, uma faç,ão deles que consegue se comunicar por ocasião da breve visita da equipe, mas por um conjunto 
complexo de outras forças, tais como facções dissidentes e brancos radicados na reserva.

$\mathrm{E}$, no que tange aos antropólogos, constatei a crescente inviabilidade de continuar desenvolvendo pesquisas sistemáticas, dissociadas do quadro desenvolvimentista, quadro este criado, involuntariamente, pelos próprios antropólogos nela engajados de uma forma maís desavisada. Parecem estar em declínio as condições mínimas para trabalhos alternativos àqueles postos em prática pela tecnocracia, já que esta detém os fundos necessários para saciar a compulsão consumista dos bororo da atualidade.

$E$, como se não bastasse, as visitas das equipes de avaliação podem causar a desestabilização do frágil equilíbrio dos sistemas politicos interétnicos vigentes nas reservas em torno da figura do "che$\mathrm{fe}^{\prime \prime}$, da "enfermeira" etc., regenerado no dia-a-dia, sem a disponibilidade de vultosos "insumos" para a realização dos seus trabalhos. Desta perspectiva, as equipes de avaliadores, integradas predominantemente por antropólogos e os próprios antropólogos que vêm às reservas munidos de sofisticados equipamentos e numerosos presentes, com os quais "compram" a fala dos índios, constituem verdadeiras ameaças ao steady state criado pelo pessoal local. Continuando o raciocínio, os antropólogos são, pelo fato de terem maior liberdade de movimentar os recursos que trazem consigo, e não por estarem submetidos às amarras da burocracia de uma Funai, detentores de um poder econômico que os torna "perigosos", além de "incômodos", coisa que eles partilham com os turistas que, quando chegam às reservas, se satisfazem com alguns artefatos maltrabalhados e logo desaparecem sem maiores vestígios.

Foi à base destas reflexões que pude entender o constrangimento e a desconfiança demonstrados pelos funcionários locais, durante os primeiros dias de nossa convivência no Posto, enquanto eu aguardava a reunião da aldeia para resolver minha situação. Sentia uma conotação agressiva em relação à categoria dos "antropólogos" durante os nossos papos após o jantar. Constatei que "antropólogo" representa, entre os bororo, alguém que não sabe trabalhar (trabaIhar braçalmente), porque só mexe com papéis e equipamentos sofis- 
ticados; dependendo da mordomia de outros (pessoal do Posto ou bororo) para sobreviver na reserva, razão pela qual integrei-me como "gente", lavando as panelas da cozinha e varrendo o chão do Posto diariamente.

Por outro lado, o "antropólogo", embora tão dependente, difama o pessoal que o acolheu com hospitalidade: é desleal e falso, pois fala o que, dentro da situação, deveria ser omitido. Em suma, o "antropólogo", à medida em que depende de outros, é visto como um parasita, e, à medida em que revela os segredos da reserva, é tido como um traidor.

Sentindo a intensidade desta carga negativa optei, adaptei-me ao "lema" do meu chefe de Posto "só come quem trabalha" Além disso, procurei demonstrar, com clareza, minha lealdade aos bororo e ao chefe de Posto, adotando algumas estratégias sugeridas por este último. Uma delas: a redação de um documento devidamente assinado pelos chefes bororo, contendo os termos do acordo entre mim e a comunidade já que, no mar de "fofocas" da reserva, o chefe poderia ser jogado contra mim, bem como eu contra ele e os bororo. Os bororo cobram do chefe de Posto lisura de comportamento dos antropólogos que entram na reserva. Tudo acertado, ninguém poderia manipular o acordo. Mas.

Dez dias após iniciar meus trabalhos em Córrego Grande, dois terços da população da aldeia foi para o Meruri celebrar um funeral, dentre eles meu mestre principal, Kadagare. Fiquei desconcertada, visto terem reiterado que não aceitariam 'o convite, desta vez, pois teriam de interromper o trabalho na roça e não tinham dinheiro para comprar comida na estrada. Também não sabiam como voltariam e queriam evitar que as crianças sofressem. Pouco tempo depois da chegada do caminhão dos xavantes, que havia sido mandado para buscá-los, este se encheu de bororo, que pularam na carroçaria munidos de panelas, malas, baquités - alguns de paletó, ostentando espingardas, outros ornados de urucu e amarraduras de algodão todos numa esfuziante euforia. E eu fiquei na reserva sem o meu "objeto"!

A esta altura, se fosse para cumprir integralmente o "contrato" estabelecido entre mim e os bororo, o melhor teria sido eu sair da reserva, já que estes não haviam assumido a sua parte. Todavia, ha- 
via um pequeno grupo de remanescentes. Tentei re-estruturar as minhas possibilidades de pesquisa às pressas, fazendo com que Kadagare, ainda antes de sair para o Meruri, autorizasse João Cândido a prosseguir no ensino das tradições.

Os próprios bororo remanescentes estimulavam-me a continuar o trabalho com o velho Cândido porque não queriam deixar de receber a sua parte dos presentes. Pouco depois, começaram a cobrar-me o mate, o fumo e a munição. Eu Ihes dizia que teríamos de esperar pela volta do pessoal do Meruri para fazer uma distribuição correta entre todos e que, ademais, eu teria o prazo de um mês para cumprir minha parte, conforme estava escrito no "papel" (acordo). Portanto, eu estava "sem pressa"

Dificil e desgastante situação essa! Raro era o. dia em que não me dissessem "Mea! Mea! (Fumo! Fumo!), "A senhora ainda não deu munição e prometeu!" "Quero mate!" Comecei a reagir, mais energicamente, respondendo: "O pessoal já voltou do Meruri? Como vou distribuir se não estão todos juntos? Depois, uns recebem antes dos outros e isto não dá certo." Este último argumento encerrava a discussão.

Além das cobranças feitas em nome da comunidade, tal como estabelecido no acordo, não faltaram pedidos de ordem individual, mais discretos e suportáveis, quando formulados pelos velhos, mas predatórios e desgastantes quando enunciados pelos jovens muito radicais. As cobranças constantes cansaram-me tanto que, já no fim do estágio, literalmente esgotada, respondi a um bororo extremamente reivindicativo, que me gritara: "O que você me trouxe de Rondonópolis?" dizendo: "Eu me trouxe a mim mesma para você!"

Logo no início do meu estágio, um jovem chefe bororo tentava me convencer que o meu gravador deveria ficar para ele. PergunteiIhe por que não poderia usar, para gravar cantos e mitos, o gravador que a "comunidade" havia recebido. Respondeu-me que este era "fechado" e guardado a sete chaves (no caso, um primoroso cestinho feito de seda de buriti, designado com o nome de "micigu") por outro jovem, de outro clã, e que monopolizava o aparelho sem quaisquer concessões. 
Fica-me claro que a luta faccional da aldeia - além de se travar no âmbito de laranjas que, para poderem ser tiradas dos pés em fazenda vizinha, implicavam na escolha de alguém que tivesse o direito de usar o trator do Posto - travava-se também no nível da tutela de gravadores.

Ainda recém-chegada à reserva e despreparada para enfrentar as artimanhas políticas do jovem chefe, passou-me pela cabeça, num repente de ingênuo sentimentalismo, que, de alguma maneira, ele tinha razão em reivindicar este gravador com que trabalhei tantos anos com eles, bororo, de modo que, moralmente, o objeto Ihes pertencia. $E$, indo mais longe ainda, o mesmo jovem bororo falou-me que, por causa disto, ele, "que será sempre chefe em Córrego Grande" (coisa que me soava um tanto estranha, mesmo assim) manteria sempre aberta a reserva quando eu chegasse.

- 0 gravador em questão era usado para realizar as transcrições das fitas gravadas com Kadagare, tarefa esta para a qual o jovem chefe tinha sido designado pelo primeiro. As transcrições chegaram a ser feitas por duas sessões, seguindo-se-lhes interrupções sistemáticas ocasionadas por brigas e desavenças com parentes até o bloqueio final desta atividade pela ida ao Meruri.

Esta interrupção deu-me a chance de refletir sobre meus atos e redefinir o arranjo: primeiro, o jovem chefe havia falhado totalmente quanto à sua colaboração na transcrição; segundo, o gravador quebrou e não havia sentido em deixá-lo nestas circunstâncias. Creio que se tivéssemos tido um diálogo aberto sobre o problema, o que não ocorreu, apenas o segundo argumento teria tido alguma validade para o jovem bororo que foi prestar serviços mais importantes. Por esta razão, tentei criar um forte respaldo moral, apregoando que o gravador quebrara, chegando a fazer demonstrações para provar a veracidade de minhas afirmações, principalmente quando apareciam os parentes clânicos do jovem chefe. Tudo indica que o esquema funcionou pois, na minha saída da reserva, o jovem chefe subiu à carroçaria do Toyota de onde eu me despedia e o assunto não foi sequer mencionado. 0 jovem chefe cobrou-me, isto sim, um par de óculos, (levei algumas armações entregues aos cuidados do chefe de Posto) para, depois, despedir-se cordialmente.

Tornou-se evidente que, para resolver a questão do gravador, dada a acirrada competição inter - e intraclânica, teríamos que inje- 
tar em cada aldeia bororo um número de gravadores equivalente ao número de chefes de famílias. Em Córrego Grande, existem dois poços, um para cada um dos dois grupos (metades) e, segundo as queixas do meu nominador, em 1978, eu errara muito pelo fato de trazer para Tadarimana uma única máquina de costura, destinada apenas aos tugareges, metade oposta à sua, os eceraes, que acabaram "ficando sem nada"

Gravadores são vistos como artefatos "nobres", muito cobiçados pelos jovens adultos, nunca pelos velhos. São cuidadosamente guardados em bolsas de palha, especialmente feitas em tecnologia tradicional, o que não ocorre com rádios e outros equipamentos sonoros, como toca-discos, por exemplo. Creio que isto decorra do fato de os gravadores constituírem técnicas novas ligadas ao mundo sagrado dos cantos e das tradições orais, razão pela qual merecem cuiJados especiais, em nítido contraste com os cadernos jogados pelas choupanas, contendo anotações de cantos. Estes contêm apenas palavras escritas, mas não sons e ritmos da música bororo, integralmente captada pelos gravadores, equipamentos de registro mais completos. Além disso, os gravadores representam depósitos mágicos de coisas masculinas muito" perigosas para as mulheres. A propósito, uma velha se negou a falar para o gravador, ordenando-me que anotasse em meu caderno. Não observei tal reação entre homens, todos dispostos a falar e a ouvir as gravações.

Técnicas sonoras atingiram maior importância social que as fotos, livros e vídeos porque se relacionam, de modo direto, com o mundo sagrado das essências, dos sons, enquanto formas, cores e movimentos sofreram, de modo mais violento, o impacto deletério das novas condições de sobrevivência: a decadência da cultura material, da pintura corporal e da plumária tradicionais. As técnicas fotográficas e visuais possuem maior importância nas relações dos bororo com o mundo civilizado, enquanto as técnicas sonoras têm relação mais direta com a dinâmica faccionada interna das comunidade.

Como me predispus a um trabalho de ênfase sonora na Córrego Grande, senti as intrincadas exigências da hierarquia de prestígio interno para poder realizá-lo e evitei utilizar a máquina fotográfica, temendo novas barganhas por parte dos bororo. Tirei algumas poucas fotos da aldeia, quase vazia, e do pessoal civilizado do Posto, para 
quem as fotos adquiriam o sentido de interesse afetivo e estímulo à sociabilidade mais descontraída após tantas tarefas diárias. Quando apareciam os bororo, eu sentia um forte constrangimento: lembravame das cenas grotescas dos turistas, fotografando índios e instalações do Posto, pessoas com as quais eu não queria ser confundida.

Em Córrego Grande, soube, pelos próprios índios, que houve problemas entre civilizados (antropólogos e fotógrafos) e bororo do Garça, durante o andamento de um funeral que precedeu aquele que motivou a saída do pessoal por ocasião da minha estada. Distúrbios teriam ocorrido, por causa das gravaçốes, filmes e fotos não-autorizàđos pelas lideranças. Soube que, em Córrego Grande, uma equipe de antropólogos e fotógráfos teria tido dificuldades graves com as tideranças locais durante funeral celebrado poúco antes de minha chegada à reserva.: Fui informada, pelo chefe de Posto e enfermeira, presentes na ocasião, que todo este pessoal fora obrigado a pagar muito caró pelos registros que fizeram.

E, para completar, padres sálesianios do Mato Grosso me informáám que estava proibida imintia entrada no Meruri: houve desavenças entre as lideranças bororo e pesquisadores presentes na área, causad̆las por filmes e gravações, rázão pela qual não se permitia mais a entrada de antropólogos. Resolvi tentâr entrar em Córrego Grande, empenhando-me por contatar o chefe de Posto, os bororo desta aldeia, por meio de contatos feitos através do rádio da Funai.

Os bororo de Córrego Grande permitiram a realização de gravacões destinadas à producão de um disco, esperando receber cerca de $C_{z} \$ 80000,00$. Um único disco só pode conter trechos de algumas das principais estrofes de alguns cantos funerários mais representativos. O lançamento do conjunto integral de cantos é, do ponto de vista comercial, inviável. Trata-se, pois, do início de um processo de "comercíalização" das tradições culturais bororo, que, ao tempo do meu régistro do funeral em Tadarimana, em 1978, era pensado como sendo propiciàdo pelos própriós antropólogos. Dizia-se, em Tadarimana, que eu iria "enricar." com a venda de fitas e fotos, em São Paulo. De certo modo, já havia o precedente de outros investigadores que levaram fotos e fitas, sem trazê-las de volta, e elaborado publicações 
cujos rendimentos acabaram por beneficiar não aos bororo, mas sim aos próprios pesquisadores.

A prática de publicar os dados etnográficos bororo em livros, desenvolvida principalmente pelos padres salesianos com base na colaboração de diversos bororo, impediu que os moradores de Tadarimana acreditassem que o meu livro, editado pelo Museu Paulista, e meus artigos publicados na Revista de Antropologia, não me rendessem polpudo dinheiro. Mais do que isso: já em 1970, trabalhando com José Maria, em Sangradouro - um dos colaboradores mais assíduos dos salesianos - ele me remetia constantemente à página $X, Y$ ou $Z$ da Enciclopédia Bororo, quando eu the vinha com minhas perguntas - "Ora, a senhora não leu direito o livro do Padre? Se tivesse lido, não estaria perguntando!" dizia-me ele, remetendo-me, por diversas vezes, à "autoridade", "ao que sabe", o padre César, muito velho, que me olhava espantado pelo fato de eu lá estar repetindo o que ele já havia feito, dizendo-me: "La pappa è fatta!"

Na Córrego Grande de 1986, Kadagare perguntou-me se eu não havia trazido "o livro" (acredito que se referia à Enciclopedia), para que pudéssemos ir discutindo os pedaços certos e errados. RetruqueiIhe que não o havia trazido, mas que estava todo na minha cabeça que também guardava o que "padre" falou em outros livros, o que "Cristóvão" (J. Christopher Crocker, antropólogo americano) havia dito em sua tese e em diversas outras publicações. Na verdade, eu tentava tenazmente escapar dos trilhos pré-moldados pela bibliografia já publicada que, conhecida nas comunidades bororo, permitia que os índios utilizassem certas "máscaras" na conversa interétnica.

Ainda mais difícil do que isto é escapar dos "trilhos" das conversas mantidas com outros antropólogos que nos precederam em campo. Fica-se cada vez menos apta a controlar as respostas, que tanto podem corresponder à opinião espontânea de um bororo quanto representar uma elaboração verbal estereotipada, que se formou à base de contatos verbais estabelecidos com outros pesquisadores.

Parece-me que, a partir dos anos oitenta, os bororos reivindicaram o controle sobre registros visuais e sonoros antes exercido pelos antropólogos. Trata-se de um momento de grande pressão sobre as terras indígenas, de frustração quanto à ineficácia dos projetos de desenvolvimento comunitário auspiciados pela Funai e da procura de alternativas, visando maior independência em relação aos tutores 
missionários e governamentais, culminando movimentos mais intensos em Meruri, em 1983, cujas repercursões atingiram as outras aldeias bororo e se ligam às lutas políticas interétnicas de outras populações tribais da região, tais como xavante, bakairi e pareci do Mato Grosso do Norte.

Neste contexto de fortes pressões reciprocas entre indios e brancos, o controle sobre o registro de imagens e sons associados às tradições culturais tem grande importância, entrando na esfera de barganha política que Ihes foi ensinada pelos próprios brancos antropólogos e missionários, por ocasião dos primeiros contatos (na área Jas missões) e dos estudos pioneiros de antropólogos (na área do rio São Lourenço, com Karl von den Steinen) em áreas bororo. Alertados para o valor de troca de suas próprias tradições, os bororo passaram a utilizá-las primeiro como meios para a obtenção de tecidos, quinquilharias, miçangas etc. e, depois, de tratores, barcos, gravadores, tambores de combustível e assim por diante.

A plenitude do mundo sonoro e visual dos bororo floresce por ocasião dos funerais, assunto imprescindivel para qualquer estudioso que com eles venha a trabalhar. O funeral é o grande "filão" não só para os antropólogos, mas, também, para os próprios bororo, os "donos" e "atores" deste grande espetáculo que tanto fascínio exerce sobre o branco, poderosa engrenagem que foge ao controle do dominador "civilizado"

A aldeia que celebra o funeral eclipsa a todas as outras, o que talvez explique a tolerância que tiveram comigo e com o meu pouco dinheiro, justamente num momento em que em Córrego Grande encerrara-se um funeral e seus moradores preparavam a partida para - Meruri. Pude, talvez, ficar apenas porque Córrego Grande estava em fase de "antifuneral" ou de "rotina" havendo, portanto, uma tendência a estabelecer compromissos de ordem racional e mais conciliadores com os brancos, meus chefes, que a eles me enviaram.

Viver numa aldeia bororo abandonada por dois terços de sua população representa passar por verdadeiro desgaste moral, que a todos atinge na reserva - pessoal da Funai, bororo e a antropóloga: 
enorme quantidade de cachorros abandonados por seus donos, uivando à noite, e, invadindo as poucas choupanas e o Posto de onde podiam cheirar alguma comida, exigindo verdadeiras barricadas na luta pela "bóia"; a parada longa do trabalho das roças, numa época em que já se iniciavam as primeiras chuvas (muito prematuras em 1986), deixando angustiados os bororo remanescentes, porque previam ter de alimentar numerosos ausentes, falando em queimar tudo para que nada tivessem a dividir; o chefe de Posto, preocupado pelo fato de ter de plantar o máximo com a ajuda de uns poucos bororo e de um amigo vizinho, para poder garantir um mínimo de mandioca para o ano; a enfermeira, prevendo a volta do pessoal doente e gripado e problemas com as crianças exaustas da viagem; as mulheres bororo, remanescentes na aldeia, queixando-se da "loucura" desta saída abrupta por praticamente três semanas, sobrecarregadas com pedidos para que "cuidassem das coisas e das galinhas" das ausentes; e a antropóloga, para quem todos estes argumentos soavam tão razoáveis, ressentida, pelo fato de ter sido "abandonada" por seus colaboradores, deprimida com um conjunto de casas fechadas, "aldeia-fantasma", sem vozes, movimento, cantos ou ruídos.

Fui envolvida pela corrente dos "antifuneralistas"! O funeral uma grande "loucura", uma grande transcendência da qual eu não participava, razão pela qual eu estava frustrada, invejando os que lá estavam. $E$, na véspera de minha saída da reserva, os bororo voltaram trazidos pelo caminhão dos padres salesianos, de forma tão repentina como saíram, roucos de tanto cantar, exaustos das danças e viagens, mas com um brilho feliz nos rostos, pois o funeral, alimentomor das almas de todos, havia sido maravilhoso. Estavam dispostos a reconstruir a sua comunidade moralmente degenerada pelo ressentimento e pela amargura dos que haviam ficado imunes a este louco "sair de si mesmo" da vida dura do dia-a-dia.

Nesta fase de ausência, o foco das atividades era representado não pela comunidade bororo, mas pelo Posto, onde foram programados diversos dias de trabalho coletivo para fabricar farinha de mandioca. Isso eclipsava a aldeia, transformada em mero lugar de dormir, e que degenerava, assim, em seu ritmo social. Ficou-me claro que, nestes momentos, é o Posto que evita a desintegração total das comunidades locais demograficamente desfalcadas que, 
representadas por poucos bororo, se integra num sistema de trabaIho "misto" (nem bororo, nem regional) composto por índios e brancos, designado "cantina" obtendo-se assim os mínimos materiais e sociais indispensáveis à sobrevivência dos remanescentes. Que contraste com um funeral "endógeno" à aldeia, quando se observa a extrema vitalidade das comunidades, a abundância de recursos e o aumento populacional, coisa que me foi possível observar na Tadarimana de 1978!

A reticência dos chefes de Córrego Grande em aceitar o convite para colaborar no funeral do Meruri se deveu, ao fato de que, certa vez, quando haviam cantado muito, nada receberam, enquanto seus anfitriões do Meruri ficaram com a "parte do leão", no caso, um veículo. Dentro da lógica bororo, os civilizados teriam de oferecer ao menos dois veículos - um para os donos do funeral, outro para os convidados de Córrego Grande. Segundo esta lógica, se estivessem representadas, digamos, quatro aldeias vizinhas em dado funeral, a questão só se resolveria de modo "certo" (segundo os ditames da hierarquia de prestígiol, isto é, se pudessem ser ofertados quatro veículos.

Em outras palavras, os presentes ofertados pelos civilizados, quando muito caros e, portanto, poucos ou únicos, exacerbam os conflitos intercomunitários, por um lado, e, por outro, aumentam as pressões de barganha dos bororo sobre os próprios brancos que com eles se relacionam. Esta é uma constatação importante para planejadores e avaliadores de programas de desenvolvimento que venham a ser implantados em áreas desta tribo.

A conjunção entre a ordem social tradicional dos bororo e a sofisticada tecnologia de ponta levada para dentro de suas reservas pelos estudiosos e curiosos do assunto, parece ter conseqüências, especialmente deletérias, no que diz respeito ao relacionamento entre as pessoas envolvidas.

Historicamente, os próprios civilizados instituíram, entre os bororo da colônia militar de Teresa Cristina de 1888, o hábito de provê-los com numerosos presentes. Para von den Steinen, os bororo eram verdadeiros enfants gatés, achando pouco tudo o que se thes 
trazia em troca da deposição das armas e de sua sedentarização, visando a abertura, para a lavoura, de imensas áreas férteis do seu território. O mesmo padrão permanece no tempo do SPI., introduzindo a obrigatoriedade de ofertas de mate, açúcar e fumo em grande quantidade. Para os bororo, o mínimo devido aos chefes de suas comunidades; para os brancos, um modo de induzir os bororo a submeter-se à sua dominação.

Instaurou-se a possibilidade de pactos de aceitação reciproca entre bororo e brancos "não-radicados", por breves períodos, e forjados do modo mais oportunístico possível - para ambas as partes Este oportunismo, levado ao extremo pelos jovens da atualidade, evoca, de certo modo, um ethos guerreiro de "saque" dos bororo de outrora que, nos primórdios dos contatos com o civilizado, procuravam despojá-los de tudo que Ihes parecesse indispensável: armas e instrumentos de ferro.

"Saquear" não é apenas tirar uma faca ou um gravador, mas é também impedir que o "inimigo" se apodere de "conhecimentos" e da "compreensão" das tradições mais caras, impiedosamente "roubadas" pelos gravadores e máquinas fotográficas. "Saquear" é, portanto, enganar o civilizado (os antropólogos) que estiver interessado nestas tradições, mitos e cantos numa aparente "amizade" ou "confraternização", omitindo ou distorcendo-as (pouco antes de minha chegada à reserva, uma pesquisadora havia saído desgastada por tais estratégias). Eu mesma senti-me num pântano desagradável quando, vez ou outra, perguntava a Kadagare a respeito das tradições de seu próprio clã e este nada dizia ou me afirmava que havia "esquecido"

A grande verdade é que os civilizados são incontroláveis, e, dentre estes, os piores, os "antropólogos" que sacam das suas máquinas fascinantes para, nas horas mais inesperadas, apoderarem-se rapidamente daquilo que custa anos para ser conquistado pela memória e paciente aprendizado de qualquer bororo. Por isto mesmo, são os que devem pagar caro pelo preço do seu próprio poder maravilhoso, o que, até certo ponto foi estimulado pela Funai, detentora de uma magra infra-estrutura material, por antropólogos e lingüistas do SIL 
(Summer Institute of Linguistics) mais bem-equipados e financiados, que inflacionaram de forma irreversível as condições de barganha recíproca entre os bororo e pesquisadores brasileiros.

A impressão que fica da Córrego Grande de 1986 é a de um grande palco em que os bororo se viam como "atores" e "donos do espetáculo", enquanto eu me sentia "espectadora", sujeita à cobrança de um caríssimo ingresso para assistir a um imenso show.

Fiquei impressionada com fato de já existirem camisetas alusivas à luta pela terra travada pelo pessoal do Meruri e de que o funeral aí celebrado teria sido um "espetáculo espantoso", congregando mais de duzentas pessoas, evocando-me os grande happenings de nossa própria sociedade urbana. Trata-se dos primeiros sintomas da influência evidente de grupos ligados à indústria cultural e que já estendeu seus tentáculos, há muito mais tempo, ao alto Xingu. Foram rodados filmes, gravados vídeos e fitas sobre o funeral, todos posteriormente editados para a apresentação ao grande público. Participarão os bororo da edição deste material e, em caso positivo, qual será o impacto causado sobre esta "sabedoria tribal", quando for revelado que os cantos devem ser reduzidos a trechos de um único disco e que as danças são mutiladas e simplificadas para se encaixarem em alguma programação de uma "Semana do Indio", ao preço de um caché irrisório?

Os bororo disputam atualmente um lugar nas discotecas e nas lojas de vídeo-cassetes dos brancos, enveredando de maneira clara pela folclorização de suas tradições culturais.

$* * * * *$

Haverá alguma fenda nesta dura muralha de representações e ressentimentos recíprocos? De um lado, os bororo, "vencidos" e ressentidos com a humilhante submissão ao branco, fruto de um exacerbado consumismo; de outro, os antropólogos, de nossa época, representantes do novo poder instituído pela Ciência e pela Tecnologia, em busca das últimas migalhas de um humanismo porventura existente num "outro" já que não o encontraram em sua própria sociedade.

Nas atuais circunstâncias, expor-me aos bororo em minha humanidade afetiva sem fazer a barganha macabra associada à minha "máscara" de antropóloga teria como efeito bloquear a pesquisa. Não 
são "homens" inteiros que se encontram na arena interétnica. São fragmentos deformados que se aglutinam sob a égide do oportunismo mais revoltante, deteriorando cada vez mais as interações e criando um fosso amargo e intransponível, antípoda de um mito que recriei para mim mesma quinze anos atrás: o de que seria possível chegar a sentir e a entender os bororo em seus segredos e em suas expressões humanas mais profundos.

$\mathrm{O}$ abismo formado pelos ressentimentos historicamente acumulados até hoje dissolveu minha esperança na construção de uma Antropologia que me permitisse voar para as "essências" bororo, no universo dos seus cenários míticos e dos seus heróis culturais, na suavidade azulada do Toroari, o morro que embeleza os arredores de Cuiabá quando se desce para o Pantanal.

Agradecimentos a:

Renato da Silva Queiroz

Pedro Zan

Gabriel Cohn,

pela paciência e leitura da versão inicial desse artigo e pelas valiosas sugestões que me fizeram, reiterando que sou a única responsável pelos erros e imprecisões que este trabalho contiver. 
FICHA CATALOGRÁFICA

VIERTLER, Renate B. Córrego Grande Revisitada. Revista da Universidade de São Paulo. São Paulo, (4): p. 119 - 142, março de 1987. 